\title{
PROFIL KEMAMPUAN BERPIKIR LOGIS MATEMATIS MAHASISWA PROGRAM STUDI PENDIDIKAN MATEMATIKA UNIVERSITAS PASIR PENGARAIAN
}

\author{
Riska Novia Sari \\ Universitas Pasir Pengaraian \\ riskanovia30@gmail.com
}

\begin{abstract}
This study aims to determine the profile of the mathematical, logical thinking ability of students of the Mathematics Education Study Program of the University of Pasir Pengaraian. This type of research is quantitative descriptive with the research subject, namely, students of the first semester of the Mathematics Education Study Program of the University of Pasir Pengaraian in the Introduction to Basic Mathematics (PDM) course. The research instrument used was a test description. The data analysis method used in this research is a descriptive percentage using the Microsoft Excel program. Furthermore, the analysis results are described based on data acquisition on the answers to the students' mathematical logical thinking ability test questions presented through tables and graphs. The results showed that the mathematical logical thinking skills of class A and B students were still low. The average mathematical logical thinking ability of each class is 52.43 and 60.42 . Furthermore, the most challenging indicator of mathematical logical thinking skills for grade A and B students is to draw conclusions or make estimates or predictions based on the correlation between two variables. Based on the research results, it is necessary to have an in-depth study of the causes of the low mathematical logical thinking ability of the first semester students of the Mathematics Education Study Program.
\end{abstract}

Keywords: Profiles, Mathematicals logical thinking skills, mathematics.

\begin{abstract}
ABSTRAK TUjuan penelitian ini yaitu untuk mengetahui profil kemampuan berpikir logis matematis mahasiswa Program Studi Pendidikan Matematika Universitas Pasir Pengaraian. Jenis penelitiannya yaitu deskriptif kuantitatif dengan subjek penelitian yaitu mahasiswa semester I Program Studi Pendidikan Matematika Universitas Pasir Pengaraian pada mata kuliah Pengantar Dasar Matematika (PDM). Instrument penelitian yang digunakan yaitu berupa tes uraian. Metode analisis data yang digunakan pada penelitian ini adalah deskriptif persentase yang dilakukan menggunakan program Microsoft Excel. Selanjutnya hasil analisis tersebut dideskripsikan berdasarkan perolehan data pada jawaban soal tes kemampuan berpikir logis matematis siswa yang disajikan melalui tabel dan grafik. Hasil penelitian menunjukkan bahwa kemampuan berpikir logis matematis mahasiswa kelas A dan B masih rendah. Rata-rata kemampuan berpikir logis matematis masing-masing kelas adalah 52,43 dan 60.42. Selanjutnya, indikator kemampuan berpikir logis matematis yang paling sulit bagi mahasiswa kelas A dan B adalah menarik kesimpulan atau membuat perkiraan atau prediksi berdasarkan korelasi antara dua variabel. Berdasarkan hasil penelitian, maka perlu kajian mendalam tentang penyebab rendahnya kemampuan berpikir logis matematis mahasiswa semester I Pogram Studi Pendidikan matematika.
\end{abstract}

Kata-kata Kunci : Profil, kemampuan berpikir logis matematis, matematika. 


\section{PENDAHULUAN}

Salah satu karakteristik dari pembelajaran matematika adalah menekankan pada proses deduktif yang memerlukan penalaran logis dan aksiomatik, yang diawali dengan proses induktif yang meliputi penyusunan konjektur, model matematika, analogi atau generalisasi melalui pengamatan terhadap sejumlah data (Sumarmo, 2013). Berdasarkan karakteristik tersebut tergambar bahwa kemampuan penalaran logis berperan penting dalam matematika. Selain itu terdapat kemampuan lain yang juga berperan penting yaitu kemampuan berpikir logis. Selanjutnya kemampuan berpikir logis memerankan peranan penting dalam pemahaman untuk menyelesaikan soal matematika (Septiati, 2018).

Berpikir logis merupakan kemampuan seseorang dalam menyelesaikan masalah tidak hanya berdasarkan prosedur yang ada, akan tetapi memiliki landasan kebenaran yang kuat dari prosedur tersebut (Syawahid: 2015). Hal ini sejalan dengan pendapat Siswono (Andriawan, 2014) bahwa berpikir logis yaitu kemampuan untuk menarik kesimpulan yang sah menurut aturan logika dan dapat membuktikan kesimpulan itu benar (valid) sesuai dengan pengetahuan-pengetahuan sebelumnya yang sudah diketahui.

Selanjutnya, Diana (2018) menyimpulkan bahwa kemampuan berpikir logis merupakan aktivitas dalam mengambil kesimpulan, menarik kesimpulan, dan melakukan pemecahan masalah. Bentuk aktivitas yang dilakukan individu dalam berpikir logis adalah ketika menjelaskan mengapa dan bagaimana suatu hasil diperoleh, bagaimana cara menarik kesimpulan dari premis yang tersedia, dan menarik kesimpulan berdasarkan aturan inferensi tertentu. Bentuk aktivitas yang lebih luas dari kemampuan berpikir logis adalah menyelesaikan masalah secara masuk akal. Kemampuan berpikir logis berbeda dengan proses menghapal. Menghapal hanya mengacu kepada proses mengingat, sedangkan kemampuan berpikir logis lebih mengacu pada pemahaman, kemampuan aplikasi, analisis, sistesis bahkan kemampuan evaluasi. Oleh karena itu, kemampuan berpikir logis sangatlah penting dikuasai dengan baik sejak menjadi mahasiswa keguruan/ calon guru, khususnya calon guru matematika.

Kemampuan berpikir logis diperlukan individu, pada saat beraktivitas dalam mengambil keputusan, menarik kesimpulan, dan melakukan pemecahan masalah. Bentuk aktivitas yang dilakukan dapat berkaitan dengan masalah matematis maupun masalah yang ditemukan dalam kehidupan sehari-hari. Aktivitas lain yang dilakukan individu dalam berpikir logis adalah ketika menjelaskan mengapa dan bagaimana suatu hasil diperoleh, bagaimana cara menarik kesimpulan dari premis yang tersedia, dan menarik kesimpulan berdasarkan aturan inferensi tertentu. Bentuk aktivitas yang lebih luas dari kemampuan berpikir logis adalah menyelesaikan masalah secara masuk akal. Seseorang dengan kecerdasan logis matematis memiliki ciri diantaranya mampu berpikir menurut aturan logika, berdasarkan struktur, menurut urutan yang sesuai, mengklasifikasi, mengkategorisasi dan mampu menganalisis angka-angka serta memiliki ketajaman dalam berspekulasi dengan menggunakan 
kemampuan logikanya. Hal ini terlihat dari penelitian Pane, dkk (2013:8) yang menyatakan bahwa siswa dapat berpikir logis ketika memecahkan masalah matematika.

Menurut Sumarmo (2012) indikator kemampuan berpikir logis meliputi: 1) menarik kesimpulan atau membuat, perkiraan dan interpretasi berdasarkan proporsi yang sesuai, 2)menarik kesimpulan atau membuat perkiraan dan prediksi berdasarkan peluang, 3) Menarik kesimpulan atau membuat perkiraan atau prediksi berdasarkan korelasi antara dua variabel, 4) Menetapkan kombinasi beberapa variabel, 5) Analogi adalah menarik kesimpulan berdasarkan keserupaan dua proses, 6) Melakukan pembuktian, 7) Menyusun analisa dan sintesa beberapa kasus.

Sehubungan dengan pentingnya kemampuan berpikir logis matematis, maka diperlukan kajian mengenai kemampuan berpikir logis matematis mahasiswa Program Studi Pendidikan Matematika Universitas Pasir Pengaraian. Melalui kajian ini akan diperoleh informasi penting bagi peneliti mengenai sejauh mana proses pembelajaran selama ini mampu menumbuhkan kemampuan berpikir logis matematis mahasiswa. Hasil yang diperoleh akan digunakan sebagai bahan evaluasi atau sebagai penentu langkah berikutnya untuk melakukan tindak lanjut, baik berupa perbaikan proses pembelajaran maupun berupa penelitian yang lebih kompleks.

\section{METODE PENELITIAN}

Jenis penelitian ini merupakan penelitian deskriptif. penelitian deskriptif menurut Sugiyono (2011) adalah penelitian yang dilakukan untuk mengetahui nilai variable mandiri, baik satu variable atau lebih (independen) tanpa membuat perbandingan, atau menghubungkan dengan variabel yang lain. Penelitian deskriptif dalam penelitian ini dimaksudkan untuk mendapatkan gambaran dan keteranganketerangan mengenai kemampuan berpikir logis matematis mahasiswa Program Studi Pendidikan Matematika Universitas Pasir Pengaraian. Subjek penelitian adalah mahasiswa semester I Program Studi Pendidikan Matematika FKIP Universitas Pasir Pengaraian yang mengikuti perkuliahan Pengantar Dasar Matematika. Teknik pengumpulan data yang digunakan adalah teknik tes. Instrumen yang digunakan yaitu tes uraian yang terdiri dari 4 soal. Metode analisis yang digunakan pada penelitian ini adalah deskriptif yang dilakukan menggunakan program Microsoft Excel. Selanjutnya hasil analisis tersebut dideskripsikan berdasarkan perolehan data pada jawaban soal tes kemampuan berpikir logis matematis siswa yang disajikan melalui tabel dan grafik.

\section{HASIL DAN PEMBAHASAN}

Tes kemampuan berpikir logis matematis diberikan kepada mahasiswa semester I Pogram Studi Pendidikan matematika yang terdiri dari 2 kelas yaitu kelas A dan B. kelas A terdapat sebanyak 24 mahasiswa dan kelas B sebanyak 4 orang mahasiswa. Data hasil tes disajikan pada Tabel 1 berikut. Data yang disajikan merupakan skor tes kemampuan berpikir logis matematis yang telah dikonversi dengan rentang 0-100. 
Tabel 1. Deskripsi Data Kemampuan Berpikir Logis Matematis Mahasiswa Indikator Kemampuan Berpikir Logis $\begin{array}{cccc}\text { Kelas } & \begin{array}{c}\text { Rata- } \\ \text { rata }\end{array} & \text { Nertingi } & \text { Nilai } \\ & \text { Terendah }\end{array}$ Matematis

\begin{tabular}{|c|c|c|c|c|}
\hline \multirow{2}{*}{$\begin{array}{l}\text { Melakukan } \\
\text { pembuktian }\end{array}$} & $A$ & 47.92 & 100 & 25 \\
\hline & $\mathrm{B}$ & 81,25 & 100 & 25 \\
\hline \multirow{2}{*}{$\begin{array}{l}\text { Menyusun analisa } \\
\text { dan } \\
\text { sintesa beberapa } \\
\text { kasus }\end{array}$} & $A$ & 75,96 & 100 & 0 \\
\hline & $B$ & 81,25 & 100 & 0 \\
\hline \multirow[b]{2}{*}{$\begin{array}{l}\text { Menarik } \\
\text { kesimpulan atau } \\
\text { membuat } \\
\text { perkiraan atau } \\
\text { prediksi } \\
\text { berdasarkan } \\
\text { korelasi antara } \\
\text { dua variabel }\end{array}$} & $A$ & 35,42 & 75 & 0 \\
\hline & B & 18,75 & 25 & 0 \\
\hline \multirow{2}{*}{ Keseluruhan } & $A$ & 52,43 & 100 & 0 \\
\hline & $B$ & 60,42 & 100 & 0 \\
\hline
\end{tabular}

Berdasarkan data pada Tabel 1 dapat diketahui bahwa nilai kemampuan berpikir logis matematis mahasiswa semester I Program Studi Pendidikan Matematika masih sangat rendah. Mahasiswa kelas A dan B masih memperoleh skor rata-rata 56,43. Nilai tertinggi yang diperoleh siswa 100. Nilai terendah diperoleh oleh mahasiswa semester I, yaitu nilai 0 . Hal ini menunjukkan bahwa terdapat siswa yang tidak dapat menjawab satupun soal kemampuan berpikir logis matematis.

Jika dilihat dari rata-rata setiap indikator kemampuan berpikir logis matematis, indikator dengan perolehan nilai terendah yaitu indikator ketiga yang meminta mahasiswa untuk menarik kesimpulan atau membuat perkiraan atau prediksi berdasarkan korelasi antara dua variabel. Rata-rata nilai indikator ketiga dari kedua kelas adalah 27,09. Indikator dengan perolehan nilai tertinggi yaitu indikator kedua yang meminta mahasiswa Menyusun analisa dan sintesa beberapa kasus. Rata-rata nilai indikator kedua dari kedua kelas adalah 78,6.

Grafik 1 berikut menyajikan rata-rata nilai setiap indikator kemampuan berpikir logis matematis mahasiswa. Grafik 1 memperlihatkan bahwa pada indikator 1 dan indikator 2, kelas B lebih lebih unggul dibandingkan mahasiswa kelas A. Namun pada indikator 3, mahasiswa kelas A lebih unggul dibandingkan mahasiswa kelas B. 


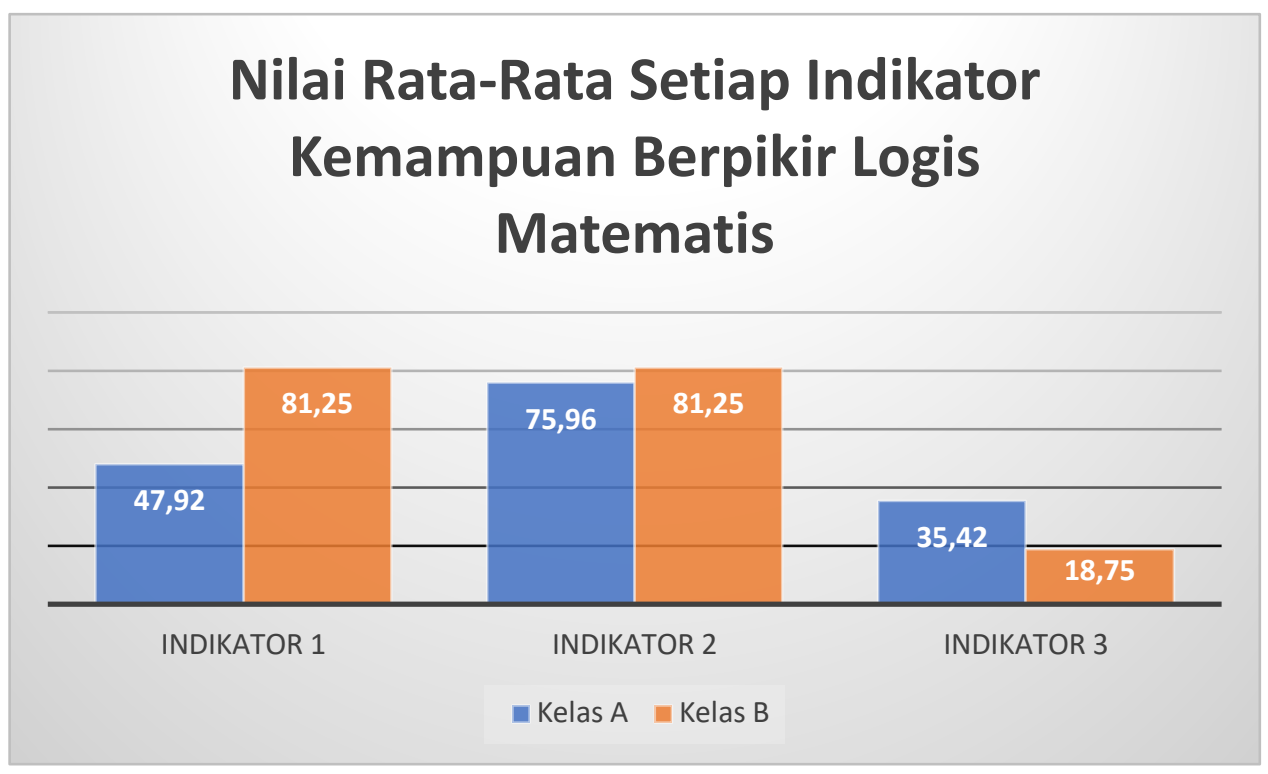

Grafik 1. Rata-rata Nilai Setiap Indikator Kemampuan Berpikir Logis Matematis

Data pada Tabel 1 dan Grafik 1 memperlihatkan suatu fakta yang unik. Masih sedikit mahasiswa kelas A maupun kelas B yang mampu menjawab soal Indikator 3. Dengan demikian dapat disimpulkan bahwa mahasiswa di Program Studi Pendidikan Matematika mengalami kesulitan dalam menyelesaikan soal-soal kemampuan berpikir logis matematis yang berhubungan dengan Menarik kesimpulan atau membuat perkiraan atau prediksi berdasarkan korelasi antara dua variabel.

Rendahnya kemampuan berpikir logis matematis mahasiswa di kedua kelas tersebut bisa disebabkan oleh beberapa hal. Perlu suatu pengkajian yang lebih dalam untuk melihat penyebab tersebut. Tindakan lebih lanjut untuk mengatasi penyebab rendahnya kemampuan berpikir logis matematis juga diperlukan untuk perbaikan kualitas pendidikan.

\section{KESIMPULAN DAN SARAN}

Kesimpulan yang diperoleh dari hasil penelitian ini adalah sebagai berikut:

1. Kemampuan berpikir logis matematis mahasiswa kelas A dan B masih sangat rendah. Rata-rata kemampuan berpikir logis masing-masing kelas adalah 52,43 dan 60.42 .

2. Indikator kemampuan berpikir logis matematis yang paling sulit bagi mahasiswa kelas A dan B adalah menarik kesimpulan atau membuat perkiraan atau prediksi berdasarkan korelasi antara dua variabel. 
Berdasarkan hasil penelitian dan kesimpulan yang diperoleh, diajukan beberapa saran sebagai berikut:

1. Perlu kajian mendalam tentang penyebab rendahnya kemampuan berpikir logis matematis mahasiswa semester I Pogram Studi Pendidikan matematika.

2. Perlu usaha serius untuk memperbaiki kemampuan berpikir logis matematis mahasiswa semester I Pogram Studi Pendidikan Matematika.

\section{DAFTAR PUSTAKA}

Andriawan, Budi \& Budiarto, M. T. Identifikasi Kemampuan Berpikir Logis dalam Pemecahan Masalah Matematika pada Siswa Kelas VIII-1 SMP Negeri 2 Sidoarjo. MATHEdunesa Jurnal IImiah Pendidikan Matematika. 3(2). 42-48.

Diana, N. 2018. Mengembangkan Kemampuan Berpikir Kreatif dan Berpikir Logis Mahasiswa dengan Adversity Quotient dalam Pemecahan Masalah. Makalah pada Prosiding SNMPM II Prodi Pendidikan Matematika Unswagati Cirebon.

Pane, dkk. 2013. Proses Berpikir Logis Siswa Sekolah Dasar Bertipe Kecerdasan Logis Matematis dalam Memecahkan Masalah Matematika. Jurnal Edu-Sains. 2(2). $14-21$.

Septiati, E. 2016. Kemampuan Berpikir Logis Matematis Mahasiswa Pendidikan Matematika pada Mata Kuliah Matematika Diskrit. Prosiding Seminar Nasional Pendidikan FKIP Universitas Muhammadiyah Palembang. 1 (1). 394-401.

Septiati, E. 2018. Kemampuan Berpikir Logis Mahasiswa Pendidikan Matematika pada Mata Kuliah Analisis Real. Wahana Didaktika. 16(2). 2017-221.

Sugiyono. 2011 . Metode Penelitian Pendidikan Pendekatan Kuantitatif, Kualitatif, dan R\&D. Bandung: Alfabeta.

Suherman. 2003. Strategi Pembelajaran Matematika Kontemporer. Bandung: FPMIPA UPI.

Sumarmo, Utari, dkk. 2012. Kemampuan dan Disposisi Berpikir Logis, Kritis dan Kreatif Matematik (Eksperimen Terhadap Siswa SMA Menggunakan Pembelajaran Berbasis Masalah dan Stratge Think Talk Write). Jurnal Pengajaran MIPA. 17(1). 17-33.

Wiji, W., Liliasari, L., Sopandi, W., \& Martoprawiro, M. A. (2014). Kemampuan Berpikir Logis dan Model Mental Kimia Sekolah Mahasiswa Calon Guru. Cakrawala Pendidikan, (1), 147-156. 